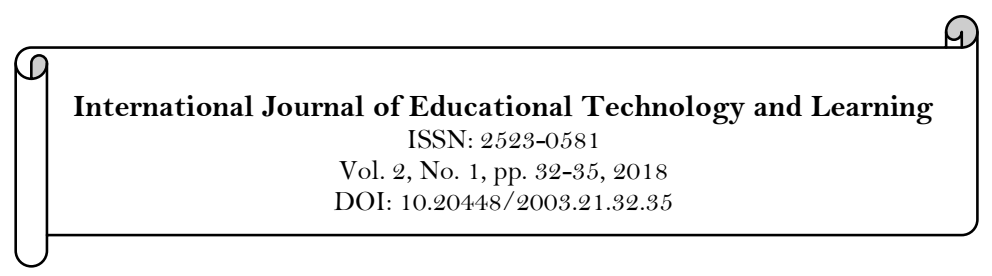

\title{
The College Choice Paradox; What Really Matters
}

\author{
Brendan Ryan \\ University of Central Lancashire and Golf Placement Service, UK. \\ Email:brendan@bmrgolfmanagement.com
}

\begin{tabular}{|c|c|}
\hline Abstract & \\
\hline $\begin{array}{l}\text { For many prospective college students and their families, the college } \\
\text { admissions process is about finding a school with a good ranking and } \\
\text { reputation and, god willing, a nationally ranked football program. } \\
\text { These families spend countless hours researching school rankings } \\
\text { and plotting their son's or daughter's entire future to ensure } \\
\text { admission into a top-ranked institution. Although this is often done } \\
\text { with good intention, such a process may not achieve the best results. } \\
\text { Admission to an elite academic school is in no way a predictor of } \\
\text { future professional success or life satisfaction. Guaranteeing success } \\
\text { is impossible; however, students, parents and counselors can increase } \\
\text { the chances of a student's success by encouraging them to focus on } \\
\text { building technical knowledge and proficiency in their core area of } \\
\text { study, as well as actively engaging in activities which allow the } \\
\text { student to build their interpersonal, leadership, critical thinking and } \\
\text { written communication skills. }\end{array}$ & $\begin{array}{l}\text { Licensed: } \\
\text { This work is licensed under a } \\
\text { Creative Commons Attribution } \\
\text { 4.0 License. } \\
\text { Publisher: } \\
\text { Scientific Publishing Institute }\end{array}$ \\
\hline
\end{tabular}

\section{College Admission; What Parents and Students Need to Know}

The admissions process is highly competitive and for many families it is also very stressful; however, all that stress is self-created. Children as young as middle school age are now being groomed to attend elite colleges. Home lives are literally being destroyed by this stress and a generation of otherwise healthy people are becoming very anxious about the college process. How? By following a path built on a heuristic. The heuristic that they have consciously or sub-consciously embraced is the belief that people who attend highly ranked schools are more successful.

Instead of checking boxes like academic rankings or size of endowment, parents, students and counsellors would be served by carefully considering how the potential school might mold the student and provide opportunities in areas which would enrich the student's life. They would do well to ask, does the school provide opportunities to grow life skills, like leadership? Or, does the location and size of the school suit this student? In looking at education this way, they need to consider the potential experience over the brand, how to use school to build advantage rather than inherit it. Being smart is one of many advantages in life, but intelligence alone does not guarantee success. Instead, people who achieve remarkable success are people who have developed a variety of strengths, including being strong communicators, capable speakers, diligent workers, or excellent negotiators. In short, the brand name of college attended neither makes someone successful nor guarantees them an experience that will enhance their chance of success in life by building advantages.

\section{The Rise of the "Professional Student"}

Early Specialization is a term used in the athletic community for youth who choose to focus considerable time and effort on a single sport at an early age. In my opinion, early specialization now also applies to academics. Today we see "professional" students, who are using deliberate practice in academics at an early age to build elevated levels of proficiency in areas ranging from math to science to spelling. In general, parents choose for their children to specialize early to gain admissions to highly selective colleges. With more and more families doing it, is early specialization worth it? Does it lead to long term success? Does it get even gain entrance into elite colleges anymore? 
Many, including myself, don't seem to think so. While academics are very important, parents and students alike must understand that life demands more than just academic competency. This idea is the foundation of Richard Learner at Tufts University's research in Positive Youth Development. Lerner fuses multiple ideologies to focus on the best practices and outcomes for youth development. According to Learner, a student's educational journey should involve building competency in up to 40 external and internal assets outside of school. For the student, building diversity in developmental assets allows them to acquire skills that transfer not just to academics, but also to life skills, such as determination, persistence, and self-motivation.

\section{Rankings as an Anchor}

Daniel Kahneman is a psychologist with notable work in the areas of decision making and behavioural economics that won him the Nobel Prize in 2002. One of his contributions is related to the heuristic of anchoring. Anchoring is when we rely too heavily on the first piece of information. This information tends to bias other relevant information. For example, someone may learn that a star colleague is a Harvard graduate and makes the assumption that he/she must be quite smart, even though they really don't know anything about their academic background or if Harvard had anything to do with their star status. They assume that it did because of the heuristic of name association.

In the college process, families and guidance counsellors are often overly impressed with the importance of standardized tests scores or academic rankings. Both anchors drive the process, yet academic research has demonstrated that the SAT is not a predictor of college performance and over 800 colleges and universities have moved to making the test optional for admissions. According to the 2017 report by the College Board only " $46 \%$ of students in the class of 2017 who took the new SAT met or exceeded the new College and Career Readiness benchmarks”.

Research by Schultz and Zedeck examine the long-term relationship between score on the LSAT and becoming a successful lawyer. In their study, Shultz and Zedeck conducted interviews with lawyers and law faculty and judges to gather information on what makes an effective lawyer. Beyond the obvious skills, like "analysis and reasoning", Shultz and Zedeck found that other skills like developing relationships or compassion are equally important to success, even though no test can accurately assess a person's ability in these areas of competency.

\section{Finland and the Program for International Student Assessment (PISA)}

Every three years, the Organization for Economic Co-operation and Development (OECD) surveys 15year-olds in reading, math and science. Since 2000, Finland, who requires little or no home-work, has ranked at the top or near top with academic super powers like South Korea and Singapore, while the USA has finished middle of the pack. Unlike the US, in Finland there is only 1 standardized test, very little homework and all colleges and universities are public, free and receive government funding. Further, Finnish Teacher programs are among the most competitive college programs to earn acceptance and to teach you must have a master's degree. When certified, teachers receive competitive wages, along with the responsibility to properly assess and create work for students.

In their high-school system, the Finns have seemed to create true diversity, with students of every economic background attending school together. Within this eclectic community, students and teachers share ideas, learn and grow in a way which has escaped American education, even after Brown vs. Board of education.

Consider that much of today's homework is little more than regurgitation which has been demonstrated to not enhance memory (Bjork \& Bjork, 2006). This means while teens from Finland are developing meaningful social connections and ridding their mind of clutter, which according to Sanford researchers Wagner and Kul help remembering, USA teens are cramming and stressing, while feeling more pressure from parents to achieve academically. Too many American students are getting the message that achievement is about "checking the boxes" of outstanding grades, community involvement and strong letters of recommendation which will earn you admission to a highly ranked school. They believe that this highly ranked school will provide an amazing education and that they will then be successful in life. Instead, parents should encourage students to find areas of interest and spend long hours learning about the subject or skill while also having time to enjoy their friends and explore other areas in art, music and athletics.

\section{The Work of Frank Bruni}

In his 2015 book, Where You Go Is Not Who You'll Be, New York Times writer Frank Bruni outlines the case for parents and students to make careful considerations of their school choice rather than basing their decisions on which schools have the most buzz. Bruni explains that parents and advisors should ignore college rankings, because they are no more than "rickety assumptions" that foster the false belief that so called "elite" schools provide students with an unequivocal advantage as they launch their careers. According to Bruni, the ideology that one school is better than the other is at best misleading, and at worst the catalyst for the destruction of self-discovery, motivation, and unhappiness for millions of adolescents. "What's troubling about the fixation on a small cluster of colleges to the exclusion of others isn't just the panic that it promotes in the 
people clamouring at the gates, [it also creates] the unwarranted feelings of failure that it creates in kids who don't make it through."

Bruni's data also suggests that attendance at such academic institutions does not necessarily warrant success on the part of the student. A study of more than 550 leaders in business, politics, and nonprofit groups found $2 / 3$ of these leaders did not attend "elite" colleges. Furthermore, such colleges also do not necessarily produce smarter students. In fact, Bruni's analysis of MacArther Genius Grants from 2009-2014 suggests that more than half of winners came from public universities or private schools that many would not generally consider amongst the highest tier.

Bruni's work helps to understand that the definition of success in college has been hijacked by numbers; unfortunately, parents feel the need to send their children to the best ranked school regardless of the variables. It is important as professionals that we work to end this thinking; college is not about checking boxes, it's about growing the intellectual, social and spiritual skills we need to contribute fully to our society and our families.

To acquire these skills does not require fancy dorms or recreation centres or high rankings, it requires opportunities to be challenged by people and ideas in a safe environment. This is important in order that students gain a deeper understanding of themselves. Finding a school that offers these opportunities, will achieve the best results for the student and they are not always the highest ranked schools!

The idea of matching skills and challenge is rooted in academic research. In Mihaly Csikszentmihalyi's research on the optimal state, which he termed flow, he suggests that one of the critical first steps is having a balance between the skills of the individual and the demands of the required tasks.

This idea has also become very popular in athletic development where Dr. Tim Lee and Dr. Mark A. Gaudagnoli termed the phrase "challenge point". The challenge point suggests that any task will present a certain level of difficulty depending on the variables of skill of the performer, task complexity and task environment. In the context of college choice, further research is needed to see how the environment of college impacts the long-term growth and skill development of the student.

\section{What is the Right Fit?}

The perfect fit for students is about finding an environment where they have the chance to excel academically while making diverse friends and learning new skills in an environment that is comfortable. When starting the search process, parents should identify schools where the student is likely to earn a cumulative Grade Point Average of over 3.5 for their college career while considering factors like how much time will it take the student to achieve $3.5+$ in the class room, class size, academic resources, percentage of professors with terminal degrees, grading scales and percent of graduates who go on to graduate degrees. By having a GPA in this range, the student has the high possibility, if necessary, to attend graduate school in the future. The student and family should also consider the campus and location; is this a place where the student feels safe and comfortable?

What is the experience going to be like? What are the dorms and cafeteria options like? What type of student is drawn to this campus? How homogeneous is the student body? What activities do the majority of student participate in? Even with all this information, remember the process of college admissions is not scientific nor based on perfect information and where ever the student decides to attend, the school will have some traits that are not ideal. The key in the process is to identify these traits, so that the student is aware of them before deciding; finding out something the first day of school will often lead to confusion and disillusionment which can decrease the chances of matriculation.

\section{Final Thoughts}

The challenge before us is helping students and their families how to properly identify and connect with schools that will ultimately help them gain the technical knowledge and social capital to become healthy, functional adults. This process is not easy; parents and students are barraged with messages of academic rankings which prey on parent's insecurities that without the best education, their children will be lost in the competitive adult world. Fortunately, academic work by people like Dr. Richard Learner, Tim Lee, M. Csikszentmihalyi, Mark Gaudagnoli, as well as popular work by Frank Bruni and Sean Faust are demonstrating that this thinking is unfounded. Their work suggests students should choose schools where they have an opportunity to engage not only academically but in other aspects of the community learning and practicing leadership, meeting diverse groups of people and testing different ideas and theories. It is these students, regardless of the institutions, who are having long term success and should be the models for our high school students.

\section{References}

Bjork, K. A., \& Bjork, R. A. (2006). Illusions of competence during study can be remedied by manipulations that enhance learners' sensitivity to retrieval conditions at test. Memory $\mathscr{E}^{\circ}$ Cognition, 34(5), 959-972. 


\section{Bibliography}

Bruni, F. (2016). Where you go is not who you'll be: An antidote to the college admissions mania. New York: Grand Central Publishing.

Csikszentmihalyi, M. (2009). Flow: The psychology of optimal experience. New York: Harper Row.

Faust, S. (2011). The Finland phenomenon [Video file]. [Accessed September 12, 2007].

Kahneman, D. (2013). Thinking, fast and slow. Toronto: Anchor Canada.

Shultz, M. M. \& Zedeck, S. (2011). Predicting lawyer effectiveness: Broadening the basis for law school admission decisions. Law Eீ Social Inquiry, 36(3): 620-661. Available at:10.1111/j.1747-4469.2011.01245. 